Finnane and Paisley: Police violence on a colonial frontier

\title{
Police violence and the limits of law on a late colonial frontier: the \\ 'Borroloola case' in 1930s Australia
}

\author{
Mark Finnane
}

Fiona Paisley

\author{
Address for correspondence: \\ Professor Mark Finnane, \\ ARC Centre of Excellence in Policing and Security \\ Mt Gravatt Campus, Griffith University, \\ 176 Messines Ridge Rd, \\ Mt Gravatt, Qld 4111, \\ Australia \\ Phone: 61-7-3735-1032 \\ Fax: 61-7-3735-1033 \\ Email:m.finnane@griffith.edu.au
}

Author note (for publication):

Mark Finnane, ARC Centre of Excellence in Policing and Security, Griffith University; Fiona Paisley, School of Arts, Griffith University. Research for this article has been supported by an Australian Research Council Discovery Grant (Finnane: DP0771492) and Griffith

University (Centre for Public Culture and Ideas). We are grateful to John Myrtle for research assistance; to Francoise Barr for her assistance at the Northern Territory Archives Service; and to Tony Roberts, historian of Borroloola and the Gulf Country, whose forthcoming book Rough Justice: a History of the Gulf Country 1900-1950 examines the 'Borroloola case' in its local and regional context. 
Finnane and Paisley: Police violence on a colonial frontier

\begin{abstract}
:
The dependence of colonisation on police was a core feature both of settler colonies and of colonial dependencies, from the middle of the nineteenth century to the post-war decline of the British Empire. After playing a key role in securing settlement against Indigenous resistance police agencies in most jurisdictions settled into a more domesticated management of social order. On still remote frontiers in northern Australia evidence of violent policing could still provoke inquiry and even prosecution of individual cases, though with limited effect. In this article we examine one such event, the death in 1933 of an Aboriginal woman at Borroloola in the Gulf Country of Australia’s Northern Territory, and the subsequent (and rare) prosecution of a policeman over her death. The factors shaping a decision to prosecute such a case, and those limiting the achievement of a measure of justice, are examined against a background of changing practices in the policing of late colonial frontiers.
\end{abstract}

\title{
$\underline{\text { Introduction }}$
}

The dependence of colonisation on police was a core feature both of settler colonies and of colonial dependencies, from the middle of the nineteenth century to the post-war decline of the British Empire. During this long century the functions and structures of colonial police were many and varied. ${ }^{1}$ We now know a good deal of their history and of their contribution to Empire. Much remains to be told of the slow processes of policing reform and especially of the politics of key events that shaped emerging models of accountability, and impeded them. In that process we see the influence of key episodes in which singular events are escalated into major political conflicts, of national and international dimension. In this 
Finnane and Paisley: Police violence on a colonial frontier

article we examine one such event, the death in 1933 of an Aboriginal woman in the Gulf Country of Australia’s Northern Territory, and the subsequent prosecution of a policeman over her death. Such a rare event as prosecution of police for violence against Indigenous people demands contextual explanation as well as estimation of the limits on legal accountability for such actions.

The 'Borroloola case' (so named by the location of its original events) is one which demonstrates both the reach of Empire and its limits, especially in respect of the ambiguous impact of law in social administration of a subordinated people. Unlike the subjects of still rebellious or subversive societies which became the object of the kinds of martial law and emergency powers characteristic of the British Empire at its peak and through its decline (as explored magisterially by Brian Simpson²), Aboriginal peoples in Australia after the decades of first contact were notionally incorporated as British legal subjects in self-governing jurisdictions which boasted a full range of appeal courts and a bureaucratic police. Amenable to the colonisers' criminal law they were nevertheless denied political and civil equality through constitutional exclusion from the Commonwealth of Australia's community of citizens, and through their liability to the oversight of 'Protection' regimes that prevailed for most of the period from the 1850s to the 1960s. In consequence the subordination of Aboriginal people was maintained through a systematic denigration of their status by practices which simultaneously infantilised and brutalised them. ${ }^{3}$ By the inter-war years the modes of administration and policing which enabled such practices were increasingly contested, within and outside government. The earlier modes of violent control (largely a nineteenth century phenomenon) had been replaced by systems of welfarist protection, founded on police powers of extraordinary scope. In the first half of the twentieth century policy towards Indigenous Australians was a preoccupation not only of government in places 
Finnane and Paisley: Police violence on a colonial frontier

usually very remote from the centres of Indigenous population but of philanthropic bodies and new intellectual disciplines (above all anthropology). ${ }^{4}$

Like some earlier episodes in southern and central Australia in which state action was pursued against those responsible for harms done to Aboriginal people, the Borroloola case was one in which prosecutors faced formidable obstacles in securing settler recognition of Aboriginal entitlement to justice. In one of the most celebrated and infamous cases of colonial New South Wales history, settler killers of Aborigines at Myall Creek in 1838 had been hung for their deeds, but only after two trials, and in the face of severe criticism of the government for prosecuting them. A white man was hung in South Australia for the killing of a black man in 1846 but he was the last such and there were no whites executed for killing blacks in Queensland. Later killers took care to cover their deeds. When those killers were police, as they were in Queensland before and after its separation from NSW in 1859, their actions were rarely called to account -- if they were, the result was disciplinary rather than punitive. In the late nineteenth century a police officer notorious for his violence was finally prosecuted in Adelaide in 1891 for killings in central Australia some years before. His acquittal after a successful defence by a leading liberal lawyer (Sir John Downer, who became a 'Founding Father' of the Commonwealth of Australia) was greeted with acclaim by most of the local urban population. Police were among those historically responsible for the killings in the Kimberley district of the northern parts of Western Australia at the end of the nineteenth century -- but when they later turned to prosecuting settlers for such killing they faced formidable obstacles of evidence and indifference, not to speak of threats from the local pastoral land-holders. ${ }^{5}$ The Borroloola case post-dated these earlier episodes of police violence by some decades, but occurred within a few years of the last reported mass killing of Aborigines, the Coniston massacre of 1927 in central Australia ${ }^{6}$. 
Finnane and Paisley: Police violence on a colonial frontier

A brief account of the settlement history of northern Australia and its modes of government, economy and policing is necessary to appreciate the context in which the Borroloola case emerged. ${ }^{7}$ The colonisation of southern Australia was all but complete by the 1850s when most colonies became self-governing. In the north however, including much of Queensland, Western Australia and the Northern Territory of South Australia the spread of settlement, through missions and cattle stations, was much more protracted. The mixed race history of the region spoke not only of the clash and accommodations of settler and Indigenous history but also of the region's proximity to South-East and East Asia, and the Melanesian Islands of the Pacific. ${ }^{8}$ In the Northern Territory the white settler population was always a small minority, but exercising economic and political power that relied heavily in early years on the possession of guns. The pattern repeated all over central and northern Australia was one of violent encounters during the early periods of contact as settlers brought their cattle onto Aboriginal lands, followed by a slow accommodation between Indigenous peoples and settlers. ${ }^{9}$ The settler economy in the north, focussed on cattle production, interrupted by occasional mining booms, became utterly dependent on Indigenous labour. Wages for these workers were low, or in-kind (especially tobacco), and had to be shared among large numbers of kin. But the accommodation also recognised Aboriginal interest in the land, with many stations becoming used to Aboriginal groups living on their leaseholds. A long term consequence of this accommodation, and of the incomplete colonisation of the north with its resilient traditions of Aboriginal ownership, was the late twentieth century government recognition of Aboriginal 'native title'. ${ }^{10}$ Many decades after the events discussed in this paper, as recently as 2003, their importance in the historical memory of the Aboriginal peoples of the region was repeatedly emphasised in the formal judicial inquiries into claims for Aboriginal land rights. ${ }^{11}$ 
Finnane and Paisley: Police violence on a colonial frontier

After a half century of administration from Adelaide in South Australia, the administration of the Northern Territory passed into Commonwealth hands in 1911. Under Australia's federal constitution most matters of domestic government remained in the control of the states, including policing, health, education and the administration of Aboriginal peoples. The transfer of the Northern Territory into Commonwealth hands was the origin of a more active interest of the Australian government in matters of domestic policy and administration. By 1930 the seat of government had been established permanently in Canberra. For day to day purposes the administration of the Northern Territory was in the hands of a local Administrator in Darwin, responsible to the Minister for Territories based in Canberra. The character of government administration for this part of Australia was thus colonial rather than self-governing; the people of the Territory had no local self-government until 1978, and their single elected representative in the Australian parliament had no voting rights until 1968. These facts of politics and jurisdiction help explain why local matters of policing and justice could become such explosive material on the national and international stage in the 1930 s.

\section{Borroloola}

For settlers Borroloola was a place of lost hopes. ${ }^{12}$ In the 1880 s it had seemed likely to have a prosperous future as a staging post along the droving routes bringing cattle from Western Queensland into the Gulf country and beyond. By the 1920s the aspirations had long since faded. Situated on the McArthur River, about forty miles upstream from its outfall into the Gulf of Carpentaria, Borroloola had four main buildings -- a police station, public house, court house and store -- all about a quarter of a mile from each other. It also boasted a legendary library -- a collection of books which was widely reported to have been a donation by the Carnegie Corporation, and which was much used by autodidacts of the region. In a 
Finnane and Paisley: Police violence on a colonial frontier

country of very demanding climate (subject to annual tropical inundation during the 'wet' season), Borroloola remained a remote settlement through which only the hardy passed. Even at the height of the Great Depression (1929-1932), at a time when numerous men took to the roads and cattle stations of the outback, this town was a stopping place for very few.. ${ }^{13}$

Two facts dominated Borroloola life and accentuated its conflicts. This was Aboriginal country, had been, was and would be. The sacred, intimate relation between Aboriginal people and their lands (a relationship which is the referent of 'country') has in recent decades become the central element in their demand for 'land rights'. When the Aboriginal witnesses in the court proceedings of the Borroloola case identified themselves, they did so in terms of their local ‘country’. By the 1930s these lands were also host to the white settlers' cattle industry . The extractive industries that would come to play such a major part in northern Australia's growth were yet to dominate this part of the country. The settler economy was organised around the production of beef cattle for export to the southern and eastern markets. The land was marginal -- very large cattle stations, no more than half a dozen within the hundred miles or so around Borroloola, dominated the local economy. The stations were occupied under grazing or pastoral leases. Indigenous peoples were essential to their maintenance, providing most of the labour on these lands. ${ }^{14}$ In 1930 Borroloola was no more (and no less) than the administrative centre and trading post of the region. Its main store was run by the man who was also the town's single justice of the peace. When necessary he would be joined on the bench by the region's other justice of the peace, a local pastoralist. There was a police sergeant, of long standing -- and usually at least one police Mounted Constable. There was also a publican, keeper of the town's single hotel.

Since the 1880s the region had a lamentable history of violence with many reports of massacres and killings of Aboriginal peoples and not a few settlers being also killed during these years. Indigenous identity was strong. Even through the pale lens of the police and 
Finnane and Paisley: Police violence on a colonial frontier

court records, and the demeaning patina of white man’s names diminishing Aboriginal individuality, one catches glimpses of people who had a strong sense of ownership of the land and membership of their local kinship and language groups. These people and the much less numerous settlers among them occupied two landscapes, one of Aboriginal names and associations (Garrwa, Yanyuwa, Borroloola, salt water country or fresh water country), the other much more recent and referencing the British origins of the dominant settler group (McArthur, Robinson, Calvert). Some names alluded to other kinds of history -- the Wollogorang station, lying to the east of the country we discuss here, bore an Aboriginal word but its reference point was the homestead of a wealthy New South Wales squatting family more than a thousand miles away.

\section{'Killem beef'}

On 9 February 1933 a court of petty sessions convened at Borroloola. There was one justice of the peace presiding, a local storekeeper and long time resident, Charlie Havey. It was the first hearing at the court since the previous 14 July when Havey and another JP (J N Macintyre, a local pastoralist), had sentenced two Aboriginal men to 6 months imprisonment for unlawful possession of a portion of a goat they had killed. This time Havey sat alone, with Macintyre unable to attend because of the flooding caused by torrential rain in the previous weeks. The number of defendants at this February heading was much greater. Fifteen men had been brought in to Borroloola by Mounted Constable Gordon Stott to face a charge of unlawful possession. Four witnesses gave evidence against them.

'By consent' the charges were heard together. Nominal defence in such cases was in the hands of the local Protector of Aborigines, in this case Sgt Raymond Bridgland, the senior police officer at Borroloola and Stott's superior officer. Bridgland's sole contribution to the defence was to question the Aboriginal witnesses in a manner implicating them in the consumption of stolen beef. The three had been participants in a 'big Sunday Corroboree' 
Finnane and Paisley: Police violence on a colonial frontier

about 'one moon ago'. Each described much the same series of events: during the recent 'big mob Blackfella', the men now held in custody had taken part in the killing of a cow. All had been party to the enjoyment of the shared meat. After the hearing, which lasted less than an hour, all fifteen were found guilty, and awarded sentences ranging from twelve months imprisonment with hard labour, to six months and three months depending on their involvement in the killing of the beast, its distribution, and consumption. ${ }^{15}$ Some defendants had been before the court previously. In 1927 Tommy Dodd, considered the ringleader in the Borroloola case, had been sentenced to six months with hard labour for the theft of household goods and food, subsequently escaping from custody after Sgt Bridgland had taken him out to help muster cattle. ${ }^{16}$ Most of the others seemed to have little earlier contact with the criminal justice system.

As much as cattle was the industry of northern Australia for the first half of the twentieth century, so the charge of unlawful possession (or the more serious one of cattle killing, difficult to prove and expensive to prosecute since it was an indictable offence and would require a trial in Darwin, some 600 miles away) was the core of police and court business. ${ }^{17}$ On the frequently marginal lands of the north white settlers from the late nineteenth century had sought to make their fortunes, droving mobs of cattle from western Queensland into the country bordering the Gulf of Carpentaria. Large fortunes were made by the early pioneers who pushed on into the Kimberley. ${ }^{18}$ In the 1880 s Borroloola had been a thriving centre but by the 1920s the early hopes for the district had faded. The expense of establishing properly maintained pastoral properties was beyond the resources of many who took up the marginal leases made available in country around the Gulf. One consequence was a thriving business in 'cattle duffing', i.e. taking cattle from herds that wandered widely over the usually boundariless leases and then rebranding them. The business of controlling Aboriginal cattle killing was thus only part of the broader police task of cattle management. 
Finnane and Paisley: Police violence on a colonial frontier

Few settlers of the Borroloola region had been free of the taint of criminal charges over involvement in cattle duffing. Ten years before the February 1933 hearing, police had sought to crack down on settlers involved in cattle duffing, many of them recent arrivals seeking to establish themselves on land they had leased since the war. Among them was Bill Harney, a thirty year-old returned soldier who had taken up a lease with his mate John (Jack) Keighran on the block they called Seven Emus. The experience of being targeted by police in this way led to Harney selling up and moving away, in circumstances he recalled with some bitterness in his many later autobiographical writings. What he did not mention there, and what may also have driven him to seek other pastures, was a police investigation into allegations by an Aboriginal woman that Harney had propositioned an Aboriginal child ${ }^{19}$.

Keighran stayed on, later taking as a partner in his lease of Seven Emus one David Cahill, an Irish-born stockman and now aspirant grazier. Cahill was a suspect in cattle duffing in the late 1920s when he was attempting to establish himself on a lease on which (so it was reported by Sgt Bridgland) there were a 'good many cleanskin [ie unbranded] cattle'. According to Bridgland, in a report he took pains to keep confidential, 'Cahill is also a man who has to be watched, as he is one who would come at any shady tricks as regards stock' ${ }^{20}$ Cahill also had a history of conflict with the other JP of the region, J N Macintyre, over their adjoining leases. By 1933 Cahill was in some financial difficulties - an outbreak of 'buffalo fly’ had led to an embargo on cattle being droved through Queensland, crippling the operation of Seven Emus. Cahill and Keighran could not pay the rent on their lease and were forced to give it up. As he sought a new venture by applying for a pastoral lease further inland on the Barkly Tableland Cahill's correspondence with Darwin was lost along with three packhorses in a flooded creek in early 1933. At least two of the Aborigines arrested by Mounted Constable Stott around this same time were employees of Cahill at Seven Emus. He had some reason to be aggravated by what probably appeared as further police harassment of 
Finnane and Paisley: Police violence on a colonial frontier

his life and opportunities. When he began to hear of what had happened on Stott's police patrol he was also angered.

The business of policing in a remote post like Borroloola was a routine of mundane duties around the main station, relieved by regular patrolling of the surrounding country, usually in response to a complaint of an offence, or intelligence of law-breaking. Mounted Constable Gordon Cameron Heaslop Stott had been at Borroloola only a short while when he was dispatched on patrol in December 1932. Possibly he had some childhood memories of the district, having been born at Borroloola in 1905 while his father, Sgt Robert Stott, was stationed there from 1904 to 1911 . He was thus a son of the Territory and of one of its better known policeman. Neither attribute seemed to add to his capacity for wise policing. Stott had a reputation of being a good bushman, but a bad policeman.

Stott’s assignment to Borroloola in late 1932 may have been a last resort for an administration that found little to recommend in his service. A posting in a remote district was the kind of thing one did with policemen who had embarrassed themselves or the service. $^{21}$ Twenty years later a review of the Territory's police found no improvement in Stott's efficiency -- 'for many years he was a drunkard ...charged and fined by the Department on many occasions ... when threatened with dismissal became a teetotaller; but his impaired mentality has never recovered ${ }^{, 22}$ Stott arrived at Borroloola under a cloud possibly of his own making. A month after reporting to duty there he found himself driven to write a letter to police headquarters in Darwin, an event recorded by his sergeant in the station police journal: 'MC Stott's report requesting inquiries be made re rumour at Katherine of he Stott being Father of half caste child'. ${ }^{23}$ The content of his defence, if such it was, and of the reply, which arrived while he was on patrol, are both lost. When he departed for patrol on 15 December he did so with the burden of someone who had been asked to account for himself. Such dilemmas presented themselves often to the men of the Territory. ${ }^{24}$ 
Finnane and Paisley: Police violence on a colonial frontier

The impact of Stott's patrol on the district was dramatic and for one person fatal. Departing on Thursday 15 December 1932 with police tracker Donegan Manarra, an Aboriginal man of brutal reputation, and their ten police horses, the party headed east towards Robinson River, Calvert Hills and beyond that to Wollogorang, a large cattle station on the Queensland border. We can map the journey through the police journals -- its daily record of miles travelled, deteriorating weather, exhausted horses, ineffectual investigation of white settler cattleduffing, the brutal arrest and forced march of Aboriginal prisoners and their witnesses for alleged involvement in cattle killing, and the death of 'Lubra Dolly', a woman who was neither 'prisoner’ nor 'witness'. On return from patrol on 8 February 1933 Stott's record of the journey was entered into the Police Station Journal -- with editing that suggests a collusion with his senior officer Sgt Bridgland. ${ }^{25}$

Stott's case against his tally of fifteen Aboriginal defendants was a fabrication. It had started with what he said was a complaint from a white station owner about an event 'five months ago or more', evidently the basis for his arrest of five people. As Stott gathered prisoners and witnesses the stories multiplied and he started to hear of a more recent event, at a corroboree ground near Borroloola -- something that he used to justify the arrest on 31 January and the following two days of another ten Aboriginal people. These later arrests were purported to be on a charge of 'unlawful possession of beef on or about $15^{\text {th }}$ January 1933 '. Yet all fifteen defendants were subsequently charged and convicted on the same vague account. Stott's consciousness of his fabrications is transparent at the very moment the charges are documented in the journal. Recounting the first arrest, of Tyson, Stott strikes out the words 'five months ago' from the charge being made. When it comes to the mass arrests for the alleged offence on or about 15 January Stott reflects all too self-consciously that 'This is a solid case -- likewise 3 other bullocks killed.' The best one can say about this entry is that 
Finnane and Paisley: Police violence on a colonial frontier

its transparent self-justification suggests a man busy constructing a case out of the flimsiest of materials.

The evidence of fabrication of the Aboriginal men's guilt was not the most damning aspect of the journal entries. For the journal record also attempted to veil the violent death of one of the Aboriginal women rounded up by Stott. Two weeks into his patrol, while at Calvert Station, Stott reported that a woman named Dolly had informed him that a white drover, Norris, was involved in local cattle duffing. For reasons undocumented in the journal, Dolly accompanied Stott as he pursued Norris cross-country. As if to provide in retrospect an explanation for his evident interest in her proximity, the police journal records that it was several days later at Robinson River Station that Stott finally 'thoroughly interviewed lubra Dolly'. Left behind at this station (or so the journal records), Dolly reappeared three weeks later, when on 23 January, Stott returned to the station with several prisoners in tow (including women witnesses, several being the wives of men he had arrested). According to a subsequent entry, Stott placed a particular trust in Dolly by instructing her to accompany Donegan late the next evening to reconnoitre a 'local blacks camp'. The two supposedly returned at 2.00 am without success. Sending Dolly out with a tracker in the middle of the night left her at risk of sexual exploitation. The more likely situation was that Dolly was left alone in the camp with Stott, a possibility best veiled in the light of circumstances later to provoke inquiry -- namely, her untimely death.

Two weeks later, the journal records that on February 2 Stott held in his custody eight prisoners on chain and seven 'loose but closely watched...' These were the fifteen men who were to be tried back in Borroloola. On this evening, the entry states that, 'Lubra "Dolly" [the quotes underlining to her future decease] complained of a pain in the lower part of her abdomen. When asked she repeated "Pox eatim guts”.' Later, the notes offer the explanation: 'Lubra Dolly suffering probably syphilis. Got witnesses to do as they suggested [to] place hot 
Finnane and Paisley: Police violence on a colonial frontier

ground from under a fire over the stomach and back.' Then, again, more retrospective diagnosis: 'Dolly complained that she was bleeding from urination. At times she appeared to be on the delirium side and yet [necessarily for Stott's case against Norris] was quite sensible at times to talk to reference to Norris stealing cattle.' If Dolly's evidence remained fit for a court of law, her poor health (previously hidden from view but, by implication, already fatally progressed) predicted her rapid demise, a process accelerated by the forced marches of a patrol hoping to beat rising rivers. Evidence of the policeman's proper concern for Dolly’s worsening condition was carefully documented in the journal entry for 4 February, rehearsing for Stott's defence, should the need arise: 'Dolly appeared to be worse in morning and laid by the fire as it was a cool day. She kept on pressing her hand on the lower part of her abdomen just above the clitoris. At 9 pm she died suddenly making a noise when breathing outwardly. Report to be furnished. Probably cancer of the womb or some other malignant disease. Buried her that night on bank of Wearyan River.' 26

Suspicion concerning the circumstance of Dolly’s death was not officially airedwhen Stott first brought his alleged cattle killers to town. But in the months to come it would become the centre-piece of the entire episode. In June 1933, responding to the interest of the Association for the Protection of Native Races [APNR], David Cahill of Seven Emus station provided a several page account of Stott's patrol, in striking contrast to the version contained within the police journal. Drawing from Aboriginal eyewitnesses, and his encounter with Stott during the patrol, Cahill reported a litany of violent acts in which prisoners were chained by the neck during the day's march and by the ankles at night. Witnesses had told him of their protests being treated with extreme brutality, including choking, blows with the butt of a revolver, and death threats with a loaded pistol. Dolly in particular had been the subject of Stott's ire: the details of Cahill's account describe sadism and suggest sexual abuse. This alternative version of events would be elaborated in the testimony of Aboriginal women 
Finnane and Paisley: Police violence on a colonial frontier

and men who survived the patrol, first at the inquiry into Dolly's death held in the Darwin Police Court on 30 and 31 October 1933, and again, at the trial for the 'ill-treatment' of Dolly resulting in her death, held in the Darwin Supreme Court in April 1934. ${ }^{27}$

But long before these inquiries into Dolly’s death, Stott's behaviour was brought into question within and outside government. Doubts about the convictions of the fifteen men brought back by Stott for cattle killing emerged within a few days of their summary trial at Borroloola. Acting on statements from other Aboriginal informants which had also been conveyed to Sgt Bridgland, Magistrate Havey heard each of the witnesses again. All asserted that they had been forced to give false confessions by Stott. These statements, along with copies of the Magistrate's Book recording the case, were forwarded to the Administrator in Darwin on 2 March. ${ }^{28}$ By 14 March the Administrator, R H Weddell, had cabled Canberra informing the Minister that: '[Both] Chief Protector and Crown Law Officer recommend that unexpired portion of all sentences should be remitted by Governor General. Glad if recommendations made urgent matter' ${ }^{29}$

Canberra acted with caution rather than expedition. The Department of Interior supported a remission of the sentences, but the Attorney-General's Department demanded attention to procedure, reminding the Minister that a petition from the convicted persons and a statement from the presiding magistrate were required before a recommendation for remission could be submitted to the Governor-General. In response, the Solicitor-General commented wryly that 'the conviction of aboriginals is perhaps a case to which all the considerations governing remissions of sentences should not be strictly applied'. Procedure prevailed, and the warrant of remission was not signed by the Governor-General until 26 June, well after the expiry of the sentences of seven of the prisoners. ${ }^{30}$ It was another fortnight before a cable reached Borroloola Police Station ordering the release of the remaining prisoners. They were now to be maintained at the station, pending an internal Board of 
Finnane and Paisley: Police violence on a colonial frontier

Inquiry into their allegations concerning Stott's behaviour. The Inquiry was to be conducted by Cecil Cook, the Chief Medical Officer and Chief Protector of Aboriginals for the Northern Territory, and Eric Asche, Crown Law Officer of the Territory. ${ }^{31}$

Physical distance as well as red tape further slowed procedure. With the inquiry also delayed by heavy rains, it was not until 19 September that the report by Cook and Asche was received by the Administrator in Darwin. Their report recommended that Stott should be dismissed, and that 'sufficient evidence of facts amounting to manslaughter' justified an inquest into the death of Dolly. Aware that their report was not to be made public, the authors seized the opportunity to raise several concerns about policing and legal procedure in the North. They noted that the accused had been charged with the misdemeanour of being in possession of beef rather than of having actually killed the beast. This lesser charge meant not only that the matter could be dealt with by a magistrate's court but that the onus of proof was weakened. Had the more serious charge of cattle killing been entered, then the matter would have gone to trial in the Supreme Court and the case would have been put to greater scrutiny. Given the paucity of evidence, the charges would have been dismissed on appeal. Aside from his misuse of police and court procedure, they found that Constable Stott 'for some reason unknown' had assaulted a woman called Dolly on a number of occasions during the patrol in question, and she had died. Their recommendations were for the dismissal of Stott and the holding of an inquest into her death. ${ }^{32}$

As the Borroloola file indicates, the Administrator, the Department and the Minister considered that Stott should be dismissed. Legal advisors warned that under the Public Service Act an officer could only be suspended while a case was pending. A conviction for charges including fabricating false evidence and assault would justify dismissal; the more serious charge of causing death by ill-treatment, depending on the outcome of Dolly's inquest, might lead to further prosecution. ${ }^{33}$ In the interim, although suspended from his duties, Stott 
Finnane and Paisley: Police violence on a colonial frontier

remained an ominous presence in Borroloola and later in Darwin, pending the hearing of the cases against him $^{34}$.

\section{Agitating the Borroloola Case}

Well before David Cahill gave his detailed account of Dolly’s death to the Reverend Morley of the APNR, he had already made public his demand for action against Stott. On 25 April 1933, the Northern Standard of Darwin published Cahill's accusations of police brutality and perversion of the course of justice in the Northern Territory. Drawing on his own experience and from accounts conveyed to him by his Aboriginal informants, Cahill made his case against Mounted Constable Gordon Stott in the hope of 'a little justice. ${ }^{35}$ This was not news to the government: by the time Cahill's letter was published, the Administrator of the Northern Territory had already forwarded to Canberra advice from the Chief Protector and the Crown law officer recommending remission of the sentences of the men charged at Borroloola $^{36}$. Cahill's letter added to the pressure to remit. A number of Aboriginal men, he contended, had been wrongly sentenced to hard labour for a crime they not only did not commit, but which had likely never occurred. Even more dramatically, he alerted the public to the violent death of one of the Aboriginal woman who, along with these men and several women witnesses, was also in Stott's custody. Her death lent a sensationalist element to Cahill's claims against Stott, and contributed to the rapid notoriety of the series of court cases, internal inquiries, reports and hearings that quickly become known among a concerned network of reformers as the Borroloola Case.

Government response to the miscarriage of justice was not Cahill’s primary concern: rather, he wanted the facts about the case to become public knowledge, perhaps for his own 
Finnane and Paisley: Police violence on a colonial frontier

reasons, as well as the noble reasons he presented to the public eye. As we have already noted, Cahill had previously come to the attention of police for suspected cattle duffing. Combined with the difficult financial conditions of the time, this unwanted experience with police likely contributed to his readiness to help prosecute the case against Stott. Cahill feared that the government would simply hold closed hearings into the case, and keep their findings confidential. The risk was that Stott would be merely moved to a new post and the case buried. Cahill realised also, that should a trial be held in open court, the Aboriginal people willing to speak about the abuses they had experienced, and of the murder of Dolly, faced a hostile reception from the local white population and police of Darwin. Cognisant that he was likely be the only white man to join them in the witness stand, Cahill knew that he was also to come under pressure. ${ }^{37}$

According to Cahill's account, it was early one morning in January 1933 while he was droving cattle with his Aboriginal workers that Constable Stott and his tracker Donegan had entered his camp. Stott accused one of Cahill's senior workers, Cliff, of consuming illegally procured beef several weeks earlier. Although Cahill countered that they had been working together on the day in question, giving clear warning that he would testify in Cliff's defence (siding with an Aboriginal man against a white policeman already a significant action in the context of local race politics), Stott 'got around' the evident impasse by immediately changing the date of the alleged crime. Cahill saw no option but to stand by as Cliff was chained by the neck to the other accused and led away into the bush. Over the next three weeks, several other men were arrested in Stott's 'round up.' Some were threatened with his loaded pistol, the majority were beaten, and two among them, including one woman, suffered deep scars still apparent weeks after their return. Seriously wounded in the leg after being beaten with a stick across his arms, legs, and back while held by a halter drawn tightly around his neck, the '[y]oung and slightly built’ Tommy Dodd, still 'frightened of Stott,' explained 
Finnane and Paisley: Police violence on a colonial frontier

later in 'pidgen English' that to 'save their beef' (their very lives) he and the others had acquiesced in Stott's version of events. Their aim was to survive the return to Borroloola and the sentences they saw as inevitable. ${ }^{38}$

Realising the case against Stott relied on the testimony of the Aboriginal protagonists, Cahill appealed to those interested in the Aboriginal cause to demand that the Australian government ensure their protection. As the court hearing would be held in Darwin, ample opportunities might arise for interference by the police and their supporters, some of whom were vocal in the local press. Among them, Jessie Litchfield, a prominent Darwin journalist, later published in a popular Australian monthly a highly critical article condemning what she considered the unfair treatment of Stott. ${ }^{39}$ Challenging 'missionaries of all denominations' working with Aboriginal people to step forward in response to such views, Cahill stated 'if you really mean to be a friend to the aboriginal' here was a 'genuine case' demanding urgent intervention. It would be a 'charitable and Christian act', he continued, to make sure that the witnesses were protected from further intimidation, both during their transit from Borroloola or while resident in the Darwin Aboriginal Compound. ${ }^{40}$

Cahill's plea for national concern was answered by the APNR. The Association was led by two religious men already deeply engaged in promoting reform in policing and legal procedure involving Aborigines in Australia. Its program was most influentially articulated by its leading member, the Reverend AP Elkin, then lecturer in charge of the Anthropology Department at the University of Sydney (the department which had been abandoned by Radcliffe-Brown in 1929). The lobby group was at the forefront of promoting new ideas about cultural sensitivity rather than the application of universalism in regard to the prosecution of Aborigines. Elkin was becoming the best-known advocate in Australia of a new approach to native administration, one endorsing the anthropological training of government officials including judges (as already provided by his department for appointees 
Finnane and Paisley: Police violence on a colonial frontier

to Australia's territories in Papua and New Guinea) and for special courts in intercultural cases as well as native courts for intra-cultural matters. ${ }^{41}$

Alongside Elkin, the Association’s honorary secretary, Reverend William Morley, proved an untiring campaigner for Aboriginal rights. A member of the Australian Inland Mission, he had become radicalised during previous years through his involvement in two of the most widely known controversies in recent Aboriginal affairs, the Forrest River and Coniston massacres of Aboriginal people by police. Morley had seen at first hand the 'ways of governments forced by public outcry to investigate allegations of wrongdoing against Aborigines. ${ }^{42}$ Nor was he to shrink from agitating the Borroloola case, anticipating its contribution towards a new era in white-Aboriginal relations in northern Australia.

In pursuing the Borroloola case, the APNR continued its larger agenda of persuading the Australian government of the need to reform the management of policing and courts pertaining to Aboriginal accused. Over following months, Morley forwarded to Minister for Interior J.A. Perkins all information received by the association from Cahill, including his detailed account of Stott's maltreatment of the prisoners and Dolly's death. As discussed later, these aims would find their most direct efforts in Elkin's personal exchanges with the Darwin judge involved in the Borroloola case, and whose comments in court would add significantly to its controversial status, including as expressed in his considerable hostility at the interest of the APNR in its outcomes. In the face of inaction from the Australian government, international pressure seemed to offer more hope of change. Within days following Cahill's April letter to the Darwin press, humanitarian commentators with international connections had begun to circulate information about the case. Among them were Anglo-Australian women with connections to the British Commonwealth League, a Dominion women's network based in London supporting the reform of Aboriginal policy that would be influential in bringing about a royal commission into Aboriginal status and conditions in 
Finnane and Paisley: Police violence on a colonial frontier

Western Australia in 1934. Significant among them were Mary Montgomery Bennett (author and missionary educator), Helen Baillie of the Brotherhood of St Lawrence (a charitable organisation which held connections with Aboriginal activists in Victoria) and Edith Jones of the Victorian Women Citizens' Movement. Along with the APNR these women were in regular communication with the Anti-Slavery and Aborigines Protection Society [ASAPS] in London (the leading international organisation concerned with aboriginal rights in the British Empire) concerning the status and conditions of Australian Aboriginal people in the various states and under federal control in the Northern Territory. Inspired by Jones, then living in England, the ASAPS had formed recently an Australian Committee focusing entirely on Australian Aboriginal matters. Like the APNR itself, this loosely knit international network was prepared to make its concerns over injustice public, while hoping to maintain amicable communications with governments in order to influence their decisions concerning policy. ${ }^{43}$

Endless letter writing was crucial to these international humanitarian endeavours. In July, for example, Jessie C. Thorne wrote to the Melbourne Herald stating that she had received a copy of Cahill's letter from Mrs Bennett. In the paternalistic and maternalistic tenor mostly typical of white concern for the rights of Aboriginal people, she pleaded ' ...for the sake of those helpless inarticulate people and also for the police constables of integrity, and those of the North who realise their responsibilities to the natives in their care...,44 Similarly, half way round the world, concerned in early May by reports of the Borroloola case appearing in the London press, Chave Collisson of the British Commonwealth League wrote to Stanley Bruce, former Australian Prime Minister and now the Australian High Commissioner in London, for information concerning the murdered 'lubra' in the case. In turn, Bruce's secretary requested information from the Australian Prime Minister's department 'regarding the case of the young girl said to have been tortured and to have been buried without an inquest being held. ${ }^{45}$ 
Finnane and Paisley: Police violence on a colonial frontier

For these internationalists the series of scandals in Aboriginal affairs in Australia in these years was evidence of the urgent need for reform. The Borroloola case showed that injustices were systemic where intercultural difference was not acknowledged, and where police were empowered without appropriate limits. Such cases renewed the internationalist determination to campaign for legal reform in settler colonial rule across the empire, and to uphold the ‘sacred guardianship’ of colonized peoples only recently asserted by the League of Nations. Australia was among newly anointed mandate nations, now responsible for the former German colony of New Guinea as well as its own territory of Papua. Controversy over the Borroloola case threatened Australia's status as one of the advanced nations of the modern post-imperial world imagined by the League. ${ }^{46}$ In international context, aside from Stott's brutality and criminality, several features of the Borroloola case pointed to endemic problems in frontier policing in Australia. First, the use of neck chaining in detaining and transporting the prisoners was condemned by the ASAPS and its Australian correspondents, all of them unpersuaded by the claims of adherents that restraint in this fashion humanely left prisoners' hands free while traversing difficult terrain. Second, the use of women as witnesses against their own husbands contravened international standards relating to the inadmissibility of a wife's evidence. Third, reform already on the books designed originally to protect Aboriginal defendants by rejecting guilty pleas without the consent of the local protector had been shown to be flawed, allowing instead for new possibilities of injustice when utilised by protector-policemen like Stott. Since a 1918 amendment, the Aborigines Ordinance had prescribed that 'no aboriginal or half-caste shall be allowed to plead guilty except with the consent of a Protector'. ${ }^{47}$ As the Borroloola case had illustrated, such provision might contribute to, rather than curtail, the capacity of a corrupt policeman to disguise his criminality. 
Finnane and Paisley: Police violence on a colonial frontier

For many, the institution of native courts promised a more effective response than reforming policing through piecemeal amendments to Aboriginal Acts. Advocates of reform (including some among government officials) sought the complete overhaul of policing in the north of Australia for Aboriginal people in little contact with or understanding of white culture. In a recent recommendation, Weddell, the Administrator in Darwin, had called for native courts to be established in the Northern Territory, but his recommendation had fallen on deaf ears. ${ }^{48}$ Adding their support to this cause, the APNR and the ASAPS pointed to the effectiveness of native courts in Southern Rhodesia where public funds were sequestered for the provision of translators and the employment of independent advocates in indigenous cases. ${ }^{49}$ In 1935 and again in 1936, the ASAPS provided for the Prime Minister of Australia an overview of the several controversial cases concerning Aboriginal witnesses and accused that had reached international attention during 1930s. Through these cases the Society emphasised key areas in urgent need of reform. It argued that judges should be trained 'with special knowledge of native laws, customs etc., [required to] conduct native cases'; that Aboriginal women be afforded the same privilege as white women under British law -'exemption from giving evidence against their husbands'; that police should not be paid for sustenance of prisoners arrested and left, sometimes for weeks, at stations en route; and that the abuse of police power was all too easily facilitated by the use of trackers for purposes other than tracking (that is, in the arrest, restraint, and custody of suspects). The ASPAS added its emphatic opposition to secret departmental inquiries, and to the inherently corrupting use of police as protectors, whereby men like Stott were both the oppressors and supposed court advocates of Aboriginal witnesses and accused. ${ }^{50}$ In a letter to the ASAPS written in 1935, activist Mary Bennett described a deathly culture of denial, advising that there were 'plenty' of murderers in the Western Australian and Northern Territory police force, but that their guilt was rarely acknowledged, nor, as in Stott's case, was it allowed to 
Finnane and Paisley: Police violence on a colonial frontier

be 'openly and fully examined ... To murder a native and then be found out is to have "too much zeal”. All murder must be done quietly. ${ }^{, 51}$

\section{The trials of Constable Stott}

By the 1930s behaviour like that of Constable Stott was an embarrassment to an Australian government intent on defending its reputation for fair administration, especially in the light of its international responsibilities for the League of Nations Mandate Territory of New Guinea. Over the six months following the outcome of the Cook-Asche Board of Inquiry, Stott faced four courts over his actions while on patrol in January 1933. Late in October a preliminary hearing in Darwin found sufficient evidence to indict him on a charge of assault against Tommy Dodd, one of the fifteen men convicted at Borroloola in February. In sensational circumstances the charge failed a few days later before a Supreme Court judge, TA Wells, new to the bench and the Territory. Barely was this trial concluded than Stott had to present himself at an inquest into the death of Dolly. Here he refused to answer any questions on the grounds of possible self-incrimination. The inquest produced equivocal evidence about the cause of death but enough to justify Stott's prosecution on a charge of assaulting Dolly. ${ }^{52}$ Stott was duly committed for trial a few weeks later before a second police court hearing, involving again a number of Aboriginal witnesses. But in April 1934 a Supreme Court trial on that count failed once more, again before Judge Wells, and involving some of the same witnesses. Remarkably Stott thus survived all attempts to bring him to account for actions which had resulted in fabricated prosecutions, and multiple instances of ill-treatment of not only prisoners but numerous Aboriginal witnesses. Perhaps the words of Donegan, the tracker, summed up the tenor of the hearings. Giving evidence that Stott had never ill-treated Aborigines, under cross-examination by the defence he stated that 'the police would sometimes give the blacks a little bit of a hiding if they were cheeky. ${ }^{53}$ Interjecting 
Finnane and Paisley: Police violence on a colonial frontier

from the bench, Wells dismissed evidence of the handcuffing of Dolly as little more than 'Field Punishment No. 1'. ${ }^{54}$ John Harris of the ASAPS, on hearing of the judge's conduct during the Borroloola case, commented, 'One can hardly understand a British judge taking the partisan attitude which Judge Wells took up without any sort of disguise. ${ }^{55}$ Stott's sixmonth suspension from duty (during which he continued to live in police barracks in Borroloola and Darwin) was recompensed with full back-pay, although the Australian government refused to pay his legal costs. ${ }^{56}$

The evidence against Stott was substantial. The determination of government and prosecutors to deal with him was also undoubted, whether this was to be achieved by dismissal, or prosecution, or both. What lay between the evidence and a successful prosecution was a complex of contextual and temporal barriers that demand attention. Chief among these were the impact of another sensational case involving the death of a policeman; the significance of the disposition of a new judge of the Supreme Court, one without previous judicial experience or knowledge of the Territory or of its social relations; and the powers of police, formal and informal, on the margins of settlement in a country where race relations were fractious, exploitative and often violent. These factors by no means exhaust the significance of the Borroloola case, which remains to this day a powerful reminder for Aboriginal people of a violent and traumatic history during the years of their dispossession. They are nevertheless crucial to understanding the failure of a system to redress gross harms during the extension of white settlement in Australia's northern regions.

Overlapping the trials of Constable Stott was the ordeal of an Aboriginal man from eastern Arnhem Land, north of the Borroloola country. Late in 1932 a number of Japanese fishermen had been killed at Caledon Bay. It was June 1933 before a police patrol set out from Darwin to track down the suspects. In much contested circumstances one of the police officers, Constable McColl, was killed on Woodah Island on 1 August 1933. When the 
Finnane and Paisley: Police violence on a colonial frontier

government threatened to despatch a further patrol to hunt for McColl's killers, widespread criticism forced its postponement. Instead, on the initiative of missionary groups and activists including Elkin, a 'peace party' sought to establish the truth about the deaths and pursue reconciliatory strategies. Only a week before Constable Stott’s second trial in Darwin on 18 April 1934, the Aboriginal man accused of killing McColl was imprisoned in Fannie Bay Gaol along with four companions, on the charge of murder. Dhakiyarr Wirrpanda had allegedly confessed to the killing but had claimed he did so after McColl had assaulted his wife. Four months after Stott's acquittal by Judge Wells on a charge of killing Dolly, Dhakiyarr was convicted and sentenced to death by the same judge. The case had already achieved international status and within a month the Commonwealth government sought to

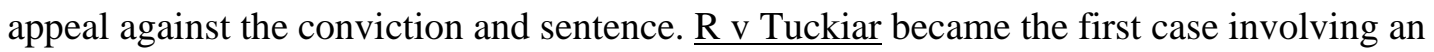
Indigenous person heard before the High Court of Australia. In November Dhakiyarr's conviction was overturned and he was released. In mysterious circumstances he disappeared after his release. ${ }^{57}$ The death of Constable McColl and the subsequent pursuit of 'police killers' dominated the public arena throughout the months in which the authorities and the APNR sought to bring Constable Stott to account for the death of Dolly.

Such a context might have been handled with more judicious reflection, and a sense of distance, by another judge. But the single judge appointed to the Supreme Court of the Northern Territory in August 1933, within a month of McColl's death, was not such a person. Thomas Alexander Wells was a Sydney lawyer with no judicial experience, a one time gunner in the Australian Army who had been badly affected by gas during service in France in 1918, a 'briefless barrister' who took the job offering in the Northern Territory at a time of economic depression $^{58}$. He had no experience of conditions in northern Australia. He knew nothing of Aboriginal people, life and culture. In Wells' view the common law and criminal law were to be applied to Aboriginal subjects of the Crown without consideration of their 
Finnane and Paisley: Police violence on a colonial frontier

particular attributes and needs. Very importantly Wells contested from the outset attempts by government and bureaucracy to temper the impact of the law's harshest penalties on Australia's last frontier. Had Wells taken up his position on law and justice from a standpoint of judicial detachment his actions might seem at the time and retrospectively more defensible. But his views were based in something more than a conventional assertion of the blindness of law. For Wells, the judge who tried Dhakiyarr, was also the local establishment figure who stood at the graveside when the remains of Constable McColl were buried in April 1934. This was not a man likely to look sympathetically at such a rare case as Aborigines charging a policeman with assault and even causing death. The conditions of law and administration in the Northern Territory delivered extraordinary power to such a person -- from May 1933 jury trial was restricted to cases involving death. ${ }^{59}$ In the cases involving Constable Stott, charges of assault rather than capital crimes, a judge alone would determine the outcome.

At the first trial of Gordon Stott, Wells presided over a case that saw successive witnesses testify to Stott's brutality on the patrol. The judge was unmoved. On conclusion of the case his finding was blunt and his allegations about the conduct of the case startling. In statements widely reported in the southern press, Wells was reported to have accused the Crown of launching the prosecution under pressure from an outside body; and of acting with star-chamber methods in gathering evidence against Stott. Protests from Morley’s Association as well as from the Territory Administration quickly brought the matter into the Australian parliament. The government prevaricated in response to demands that Wells be made to account for his remarks, but Wells himself responded quickly to criticism in the national parliament. He proved a dissembler, claiming to have been misrepresented and misquoted. He had, he said, 'expressly stated that I did not know whether or not it was fact that the Crown had brought the proceedings at the instance of an outside body'. But the copy of his judgment provided to the government showed that he had gone much further than that 
Finnane and Paisley: Police violence on a colonial frontier

in concluding that 'strong colour is lent to that suggestion by the attempted appearance here by counsel acting for some body calling itself the Aborigines Protection Society. ${ }^{, 60}$

Morley and Elkin and most southern opinion could only proceed on the basis of what best information they could obtain at a distance. Those who knew the case intimately through talking directly with those Aboriginal witnesses whom Wells dismissed so lightly were outraged by his claims. David Cahill wondered whether the Crown had really prosecuted the case adequately anyway; he was particularly incensed at what he saw as police manipulation of witnesses. 'It seems to be hopeless to try and get justice for the natives especially while the police are protectors', he told Morley. As for Stott's claim that he had been denied a chance to cross-examine witnesses during the Cook-Asche Inquiry at Borroloola, Cahill was scathing: 'well I was there while ten witnesses was being put through and he cross examined every one of them. When Stott can get away with statement like that I agree with Charles Dickens that the law is a hass' ${ }^{61}$

Cahill was not to know it but within the Northern Territory administration Stott's claims of unfair treatment, and Wells' acceptance of them, were being hotly contested. The Chief Protector, Cecil Cook, was dismayed by Wells' attack on those who had purportedly denied Stott his rights during witness examinations prior to the trial. In a letter to the Administrator, immediately passed on to Canberra, Cook refuted Stott's claims to have had no chance of cross-examination. Some witnesses examined by Cook and Asche had been 'manifestly afraid, one shivering with fright throughout his examination'. Stott had been invited to leave while examination of some witnesses continued and had done so, without surrendering his right to cross-examine on a statement of the evidence at a later hour, which he did. In spite of all, Cook insisted that at the end of the enquiry he had in his possession, testimony in my opinion unshaken by Stott's liberal cross-examination that a number of aboriginals were systematically intimidated over a period of days. The evidence 
Finnane and Paisley: Police violence on a colonial frontier

appeared to show that statements and confession elicited under duress were tested at different camps with a view to drilling their authors into a spontaneous statement on arrival at Borroloola. It further appeared to show that Tommy Dodd, who made a statement at Coolafella Creek at the point of Stott's revolver was taken as a witness but recanted at Robinson River and was assaulted and made a prisoner accordingly.

This was the kind of evidence on the basis of which Cook and Asche had recommended Stott be dismissed and had mooted a manslaughter charge over the death of Dolly. So agitated was Cook by Wells' caricature of the case against Stott that he threatened resignation from his office of Chief Protector. ${ }^{62}$ The near to absolute immunity of judges rendered protests of this kind nugatory.

The second trial of Constable Stott was held in April 1934. We have already noted the less than propitious circumstances -- especially the arrest of Dhakiyarr, the suspected killer of a policeman, in Darwin the week before Stott's trial. On that same day Wells had sentenced to death another Aboriginal man, Nemarluk, for the murder of a Japanese fishermen at Point Keats in $1931^{63}$. Stott's trial lasted three days, its relatively lengthy duration necessary because of the large number of witnesses (sixteen in all) brought by the Crown. In the middle of the trial, on Sunday 22 April, Wells attended McColl’s funeral: photographs of the event show him at the graveside, hat in hand, the most prominent of mourners at the funeral of a man he had never met, and whose alleged killer he would subsequently try and sentence to death. ${ }^{64}$ On the following day the judge showed he was in no mood to tolerate what he continued to regard as meddlesome people in Sydney who 'herd in their drawing rooms and talk about events taking place thousands of miles away'. He acquitted Stott on the charge of assaulting Dolly, a charge rendered hopeless anyway in Cahill's view because the Crown had not specified the date of the assault in a way consistent with evidence he could give about his own observations of Dolly’s mistreatment. Wells was unrestrained in his dismissal of the 
Finnane and Paisley: Police violence on a colonial frontier

charges, and contempt for the value of Aboriginal evidence, describing the witnesses as liars. 'If prosecutions of this sort are to be continued members Northern Territory police would be better off humping their bluies' (ie become itinerant workers) ran the report of Wells' comments, cabled to Canberra ${ }^{65}$. In a parting shot, the judge expressed his sympathy for Stott and promised to consider whether he could make an order for the Crown to pay the defendant's costs. The next day Stott was reinstated.

Canberra was consulted and Judge Wells was advised that he could not make an order for the Crown to pay costs. In his concluding comment in court Wells suggested the Commonwealth should nevertheless consider paying Stott's costs in the second trial. The Territory administration and the department in Canberra were at one on this matter -- Stott's costs should not be paid. In the face of judicial criticism the view persisted among government officials that the case had been soundly based. At the heart of the Stott trials was the credibility of Aboriginal evidence. The senior bureaucrat J A Carrodus (Acting Administrator at the time, based in Darwin) put the matter succinctly in defending the decision to prosecute not once but twice, especially on the evidence relating to the assault on Dolly. 'The Judge evidently expected that each aboriginal witness should corroborate every detail of evidence given by the others', he noted, but the impediments to such an outcome were great and linked to matters of language and interpretation. The questions had been asked and answered in 'pidgin English’: 'it was perfectly clear, on many occasions during the trial, that the aboriginal witness did not understand the question asked and was replying at random to what he assumed the question to be'. In spite of these difficulties 'practically the whole of the witnesses could not be shaken on the material fact, namely that Stott did assault the lubra Dolly,. ${ }^{66}$ In addition there had been a sustained and successive number of inquiries that had led in the same direction, justifying the prosecution of Constable Stott. 
Finnane and Paisley: Police violence on a colonial frontier

Judge Wells not only survived the controversy but maintained his prickly behaviour and contempt for the people whose fate he helped determine. This is not the place to explore the longer record of his resistance to legal reforms that would recognise the distinctive status of Aboriginal defendants and witnesses. ${ }^{67}$ But the obduracy of Wells was not the only thing standing between the prosecution and a conviction. Our discussion earlier of the conditions of policing in the Northern Territory, and of the particular record of Stott's patrol has highlighted the exceptional state of police relations with Aborigines in northern Australia at this time. Throughout the year that followed Cahill's public airing of Stott's behaviour, the required independence of police was compromised repeatedly by decisions that set Aboriginal interests at nought and enabled Stott to survive. How far those decisions were intentional and how far the result of circumstance remains in doubt. As much as Sgt Bridgland might have wished to protect a fellow police officer, he was also directly responsible for initiating a review of the Borroloola prosecutions. Yet Cahill was in no doubt that the conditions under which Aboriginal witnesses were selected, transported hundreds of miles, and accommodated in Darwin over long periods of time away from their country, amounted to intimidation. The Chief Protector was also in no doubt about the fear that Aboriginal witnesses exhibited in Stott's presence during the conduct of his inquiry accompanied by the Territory’s chief law officer. In spite of being suspended from duty during the months of his trials, Stott remained in residence at the Borroloola station. The realities of policing on the frontier (paradoxically, given its vast distances), brought police and policed, suspect and accuser, victim and assailant, into extraordinary proximity. Even in the aftermath of his public condemnation of Stott, Cahill was relying on this same Mounted Constable to convey messages to his commercial partners and others across the tens and hundreds of miles of the Borroloola district. In retrospect one may wonder not that Stott survived the evidence against him, but that the case had ever got off the ground. 
Finnane and Paisley: Police violence on a colonial frontier

\section{Conclusion}

The prolonged saga of the Borroloola case can only be understood against a background of transition in policing Indigenous peoples in a settler society in the early twentieth century. The relatively late expansion of white settlement into remote areas of northern Australia is the context for the events we have discussed here. By the 1930s policing and judicial practice in most parts of Australia had developed approaches with recognisably modern forms and procedures. Their dealings with the country’s Indigenous peoples were framed by the norms of two styles of policing -- criminal justice and welfarist. Under policies of neo-colonial burden, the welfare regimes subjected large numbers of Aboriginal people to disabling 'protectionist' controls -- removal to reserves, removal of 'half-caste' children into state control, management of wages ${ }^{68}$. When they committed criminal offences such people were also subjected to the usual processes of criminal law, though usually modulated through the welfarist presumptions of State and Commonwealth governments, an exception being the rare experiment in justice attuned to the specific status of Indigenous people, in the Native Courts of Western Australia (1937-1954). ${ }^{69}$ In most contexts Aboriginal people were simultaneously the subjects of welfare interventions on a totalitarian scale, while denied in criminal law the recognition of their particular status and legal disabilities.

Against this background the violence of Constable Stott, and the sorry farce of Judge Wells’ Court, stood out in bold relief, highlighting historical abuses, government indifference and the lack of remedies. National and international attention proved poor matches for the stubborn resistance of institutions that could become hostages of their own procedural and political conditions. As we have seen, the very highest levels of responsible authority were ready to remove Constable Stott from police service in 1933 and have him prosecuted on the gravest charges. Failure to remove Stott from police service reflected an entrenched 
Finnane and Paisley: Police violence on a colonial frontier

commitment to the entitlements of public servants, in spite of the ambiguities in police status. ${ }^{70}$ Failure to achieve successful prosecution of Stott spoke volumes for the multitude of problems facing any attempt to bring to account white settlers for abuses against Aboriginal people. The judge, sole decision-maker in a trial without jury under the conditions prevailing in the Northern Territory, exhibited a disposition that was almost a caricature of colonial chauvinism. But David Cahill pointed to a larger truth when he blamed the prosecution for its mishandling of the case. The reluctance of government to proceed with determination is highlighted by the failure to make an example of the judge by appealing the outcome of either trial. Justice was not absent in this outpost of late colonialism, it was simply all too conditional.

There were signs of change in policy. A year after the failure of the second trial of Constable Stott, another Northern Territory policeman was the subject of a Commonwealth board of inquiry for his gross ill-treatment of prisoners and the shooting of an escapee. ${ }^{71}$ Like Stott, this policeman survived scrutiny, but the accumulation of ill-treatment of Aboriginal prisoners, together with the advocacy of Elkin and others for a change in administration, led to the significant creation in 1936 of the new office of 'Patrol Officer', bringing other colonial modes of 'native administration' into Australia. ${ }^{72}$ Such remedies were too late for the victims of the Borroloola case. But Stott's conduct was throughout seen as running against a policy agenda that was shaping the movement from the hard policing of the frontier towards the softer administration of the Patrol Officer. Hence at a national level the Borroloola case added to the momentum for change in the administration of justice. The failures of the Stott prosecutions were a stimulus to the efforts of Morley, Elkin, the APNR and others to bring about a wholesale change in the administration of justice, an exercise in which they would be continually disappointed. In June 1934 they pressed the government to take an appeal to the High Court, a case seemingly supported by the Secretary of the Department of the Interior on 
Finnane and Paisley: Police violence on a colonial frontier

the grounds of the evident bias of the judge. In July the APNR pressed for a Royal Commission. Both approaches went unheeded. Ever hopeful of positive reform, Morley worked hard to keep the matter of Aboriginal justice in the north on the minister's agenda. He hoped for something from a trip by the Minister to Darwin in 1935 with the asserted objective of gaining a first hand overview of the troubling relationship between northern courts and Aboriginal accused. After the Minister reported back that he had seen nothing that would warrant a Royal Commission, an exasperated Morley wrote later to a London sympathiser: '[W]e never expected a tragedy to be enacted during his visit. Bad boys are always very good whilst the School Inspector is about' ${ }^{73}$ As the senior bureaucrats kept telling the Ministers, decisions to appeal court judgments or establish Royal Commissions were 'a matter of policy’. The ultimate responsibility for what happened in matters like the Borroloola case was a political one -- and political conditions on policy concerning fundamental justice to Aborigines proved intractable for decades to come.

\footnotetext{
${ }^{1}$ See especially David Anderson and David Killingray, Policing and decolonisation : politics, nationalism, and the police, 1917-65 (Manchester: Manchester University Press, 1992); David Anderson and David Killingray, Policing the empire : government, authority, and control, 1830-1940 (Manchester: Manchester University Press, 1991); Richard S. Hill, Policing the colonial frontier : the theory and practice of coercive social and racial control in
} New Zealand, 1767-1867 (Wellington, N.Z.: V.R. Ward, 1986).

${ }^{2}$ A. W. Brian Simpson, Human rights and the end of empire : Britain and the genesis of the European Convention (Oxford: Oxford University Press. 2001), esp Ch 2 'Mechanisms of Repression'; see also David Anderson, Histories of the hanged : the dirty war in Kenya and the end of empire (New York: W.W. Norton, 2005); Catherine Hall, Civilising subjects : metropole and colony in the English imagination, 1830-1867 (Cambridge: Polity, 2002); R. 
Finnane and Paisley: Police violence on a colonial frontier

W. Kostal, A jurisprudence of power : Victorian Empire and the rule of law (Oxford: Oxford University Press, 2005).

${ }^{3}$ Bain M. Attwood, Rights for aborigines (Crows Nest, N.S.W: Allen \& Unwin, 2003); John Chesterman, Civil rights : how indigenous Australians won formal equality (St Lucia, Qld: University of Queensland Press, 2005); Bruce Kercher, An unruly child: a history of law in Australia (St Leonards: Allen \& Unwin, 1995).

${ }^{4}$ Anna Haebich, Broken circles: fragmenting indigenous families 1800-2000 (Fremantle: Fremantle Arts Centre Press, 2000); Andrew Markus, Governing savages (Sydney: Allen \& Unwin, 1990); Russell McGregor, Imagined destinies: Aboriginal Australians and the doomed race theory, 1880-1939 (Carlton, Vic.: Melbourne University Press, 1996); Tim Rowse, White Flour, White Power: From Rations to Citizenship in Central Australia. (Melbourne: Cambridge University Press, 1998).

${ }^{5}$ Alan Atkinson, The Europeans in Australia : a history. Volume Two: Democracy. (Melbourne: Oxford University Press, 2004), ch. 8; Mark Finnane and Jonathan Richards, "'You'll get nothing out of it'?: the inquest, police and Aboriginal deaths in colonial Queensland." Australian Historical Studies 123 (2004): 84-105; Gordon Reid, $\underline{\text { A Picnic with }}$ the Natives: Aboriginal-European Relations in the Northern Territory to 1910 (Carlton, Melbourne University Press, 1990); Amanda Nettelbeck, "Writing and remembering frontier conflict: the rule of law in 1880s central Australia." Aboriginal History 28 (2004): 190-206; Amanda Nettelbeck and Robert Foster, In the name of the law : William Willshire and the policing of the Australian frontier. (Kent Town, S. Aust.: Wakefield Press, 2007) for South Australia; Chris Owen, "'The police appear to be a useless lot up there': law and order in the East Kimberley 1884-1905." Aboriginal History 27 (2003): 104-130; D. John Mulvaney et al. From the frontier : outback letters to Baldwin Spencer (St Leonards, NSW: Allen \& Unwin, 2000); Jonathan Richards, The secret war: a true history of Queensland's native police (St 
Finnane and Paisley: Police violence on a colonial frontier

Lucia, Qld: University of Queensland Press, 2008); Peter Vallee, God, guns and government on the Central Australian frontier (Canberra: Restoration, 2006).

${ }^{6}$ Bill Wilson and Justin O'Brien, "'To infuse an universal terror': a reappraisal of the Coniston killings." Aboriginal History 27 (2003): 59-78.

${ }^{7}$ Tony Austin, Never trust a government man : Northern Territory Aboriginal policy 19111939 (Darwin: NTU Press, 1997); Tony Austin, Simply the survival of the fittest : Aboriginal administration in South Australia's Northern Territory 1863-1910 (Darwin, Historical Society of the Northern Territory, 1992); Markus, Governing savages. ${ }^{8}$ Regina Ganter Mixed relations : Asian-Aboriginal contact in North Australia (Crawley, W.A.: University of Western Australia Press, 2006); Henry Reynolds, North of Capricorn : the untold story of Australia's north (Crows Nest, NSW: Allen \& Unwin, 2003).

${ }^{9}$ Richard Kimber, “Genocide or not? The situation in Central Australia, 1860-1895”, Genocide perspectives I : essays in comparative genocide ed. Colin M. Tatz (Sydney: Centre for Comparative Genocide Studies, Macquarie University, 1997); Tony Roberts, Frontier justice : a history of the Gulf country to 1900. (St Lucia, Qld: University of Queensland Press, 2005); Vallee, God, guns and government.

${ }^{10}$ Through both legislation and judicial decisions at Commonwealth and state levels from the 1970s on - see Paul G. McHugh, Aboriginal societies and the common law : a history of sovereignty, status, and self-determination. (Oxford: Oxford University Press, 2004). ${ }^{11}$ See especially Australia Office of the Aboriginal Land Commissioner, Seven Emu Region land claim no. 186, Wollogorang Area II land claim no. 187 and part of Manangoora Region land claim no. 185 / report and recommendations of the Aboriginal Land Commissioner Justice H. W. Olney to the Minister for Immigration and Multicultural and Indigenous Affairs and to the Administrator of the Northern Territory (Canberra: Office of the Aboriginal Land Commissioner, 2003) p. 48 and generally pp. 40-58. The first inquiry into an Aboriginal land 
Finnane and Paisley: Police violence on a colonial frontier

rights claim under Commonwealth legislation of 1976 was in fact in the Borroloola country: see Australia Office of the Aboriginal Land Commissioner, Borroloola land claim : report to Minister for Aboriginal Affairs and to Minister for the Northern Territory (Canberra: AGPS, 1979). An influential documentary made in the late 1970 s documented many of the issues involved in this survival of Aboriginal culture and possession of country, including events covered in this paper: see A. Cavadini and C. Strachan, Two Laws (1981).

${ }^{12}$ The essential introduction, dealing with Borroloola's brief flourishing and early decline, is Roberts, Frontier justice. For the Aboriginal history of the area see Richard M. Baker, Land is life: from bush to town : the story of the Yanyuwa people (St Leonards, NSW: Allen \& Unwin, 1999).

${ }^{13}$ One who became a legend was Roger Jose, a hermitic character who lived with his Aboriginal wife in an inverted water tank - in the year in which the events we describe here took place Roger Jose was employed casually on relief work, usually clearing timber from the police horse paddock, an arrangement subject to authorisation from the Northern Territory Administration in Darwin, some 600 miles to the northwest. On Jose see Ted Egan,

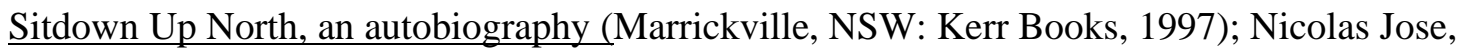
Black sheep : journey to Borroloola (South Yarra, Vic: Hardie Grant Books, 2002), and NTRS 2086 Borroloola Police Journals 1932-1934 (Northern Territory Archives Service, hereafter NTAS).

${ }^{14}$ Baker, Land is life; Ann McGrath, "Born in the cattle" : aborigines in cattle country. (Sydney: Allen \& Unwin, 1987).

${ }^{15}$ NTRS 2689/P1, Borroloola Magistrates Book,, Feb 9 1933, NTAS.

${ }^{16}$ During their period of incarceration Aboriginal prisoners provided additional town and police labour. NTRS 2709 (was F 271), Register of reported felonies, Borroloola, NTAS 
Finnane and Paisley: Police violence on a colonial frontier

${ }^{17}$ Mark Finnane and John McGuire "The uses of punishment and exile - Aborigines in colonial Australia." Punishment and Society, 3 (2001): 279-298; Dawn May, Aboriginal labour and the cattle industry : Queensland from white settlement to the present (Melbourne, Vic., Cambridge University Press, 1994); Nettelbeck and Foster In the name of the law;

Owen, "Law and order in the East Kimberley 1884-1905".

${ }^{18}$ Most famously the Durack family - Mary Durack, Kings in grass castles (London:

Constable and Company, 1959); Mary Durack, Sons in the saddle (London: Constable, 1983).

${ }^{19}$ NTRS 2086, Borroloola Police Journal, 16 Dec 1922 (NTAS); W. E. Harney, Content to lie in the sun. (London, R. Hale, 1958).

${ }^{20}$ Bridgland 22 Nov 1929 to Secretary, North Australia Commission Darwin, F28 Box 12 Item no GL 380, NTAS.

${ }^{21}$ W. R. Wilson, 'A force apart? a history of the Northern Territory Police Force 1870-1926' (Darwin, NT: Charles Darwin University. PhD, 2000) pp. 136-138; cf Nettelbeck and Foster, In the name of the law, on the South Australian postings of William Willshire after his acquittal on a charge of murder in 1891.

${ }^{22}$ W. J. McLaren, The Northern Territory and its Police Forces, (Unpublished, NTAS, 1982), p. 1191.

${ }^{23}$ NTRS 2086, Borroloola Police Journal, 1932-1934, 8 Nov 1932 and 19 Jan 1933 reporting a reply from HQ, without detail, NTAS.

${ }^{24}$ They achieve their fictional representation as a moment in the moral decline of a central character in Xavier Herbert's Capricornia, when Mark Shillingworth fails to keep news of his half-caste child from his white wife in Darwin: Xavier Herbert, $\underline{\text { Capricornia : a novel. }}$

(Hawthorn, Vic: O'Neil, 1971 [1938]); see also McGrath, Born in the cattle.

${ }^{25}$ NTRS 2086 Borroloola Police Journal 1932-1934, 8 Feb 1932 (fols 173-184), NTAS.

${ }^{26}$ NTRS 2086, Borroloola Police Journal, 1932-1934, 8 Feb 1933, NTAS. 
Finnane and Paisley: Police violence on a colonial frontier

${ }^{27}$ Cahill's nine page letter to Morley, June 23, 1933, APNR drew upon information conveyed to him by Aboriginal witnesses, Cahill to Morley, 23 June 1933, National Archives of Australia (hereafter NAA), A1 (A1/15), 1933/5423

http://naa12.naa.gov.au/scripts/imagine.asp?B=45548\&I=1\&SE=1 (8 Jan 2009), and see newspaper clippings of Stott's trial contained in the Borroloola file, recording extracts from Aboriginal evidence in court.

${ }^{28}$ Borroloola Police Journal, NTRS 2086 1932-1934, 28 Feb, 2 Mar 1933 , NTAS.

${ }^{29}$ Weddell (Darwin) to Department of Interior (Canberra), 14 Mar 1933, NAA A1 (A1/15) 1933/5423.

${ }^{30}$ Carrodus (Interior) to Administrator (Darwin), 28 Jun 1933 (fol 56); Brown (Interior) to AGs Dept 13 Jun 1933, (fol 48), NAA A1 (A1/15) 1933/5423.

${ }^{31}$ NTRS 2086, Borroloola Police Journal, 1932-1934, 11 Jul 1933 (fol 265).

${ }^{32}$ Cook and Asche Report, 19 Sep 1933, NAA A1(A1/15), 1933/5423 (fol. 101).

${ }^{33}$ Brown (Interior, Darwin) to Interior (Canberra), 25 Sep 1933, and related correspondence, NAA A1(A1/15), 1933/5423. On the matter of inquests and their part in policing, see also, Finnane and Richards, 'The Inquest, Police and Aboriginal Deaths in Colonial Queensland'. ${ }^{34}$ H J Foster to Morley, 24 Apr 1934, NAA A1 (A1/15) 1933/5423.

${ }^{35}$ Death of Borroloola Lubra’ Northern Standard, Tuesday April 25, 1933, NAA A1 (A1/15), $1934 / 5423$.

${ }^{36}$ Telegram, R H Weddell, to Interior, 14 March 1933, NAA A1 (A1/15), 1934/5423.

${ }^{37}$ In the following months, Cahill was subpoenaed for his letters and telegrams with the APNR, his mail was tampered with, and he faced a libel action by Stott. See Cahill to Helen Baillie, 20 January 1934, Cahill to Morley, 29 April, 1934, and Horace Foster to Morley, 24 April 1934, NAA A1 (A1/15), 1934/5423. 
Finnane and Paisley: Police violence on a colonial frontier

38 'N.T. Constable Charged: Assault on Native Alleged.', Melbourne Herald, 30 October 1933, NAA A1 (A1/15), 1933/5423.

${ }^{39}$ Jessie Litchfield, 'Recent Murder Trials at Darwin’, TO-DAY, October 1934, p. 14, 15 , and 30.

40 'Death of Booroloola [sic] Lubra: Inquiry Asked for: Startling Allegations: Treatment of Abos', Letter-to-the-editor, Northern Standard (Darwin), 25 April, 1933, NAA A1 (A1/15), 1933/5423.

${ }^{41}$ A.P. Elkin, "Anthropology and the Future of the Australian Aborigines." Oceania v(1) (1934): 1-18. See also Russell McGregor, 'Wards, Words and Citizens: A.P. Elkin and Paul Hasluck on Assimilation’, Oceania, 69 (1999): 243-259; Geoffrey Gray, A cautious silence: the politics of Australian anthropology (Canberra. Aboriginal Studies Press, 2007); Mark Finnane, "The tides of customary law." $\underline{\text { ANZLH E-Journal (2007) }}$ http://www.anzlhsejournal.auckland.ac.nz/pdfs_2006/Keynote_1_Finnane.pdf, pp. 6-8. ${ }^{42}$ Markus, Governing Savages, pp.161-162; Andrew Markus, ‘Morley, William (1854? 1939)', Australian Dictionary of Biography (Melbourne: Melbourne University Press, 1986, 10: 588-589) http://www.adb.online.anu.edu.au/biogs/A100572b.htm?hilite=morley\%3Bwilliam (8 Jan 2009). On Coniston see Wilson and O'Brien (2003), 'A reappraisal of the Coniston killings'; Rowse, White Flour, White Power; on the more contested historiography of Forrest River see Neville Green, The Forrest River massacres (Fremantle, WA: Fremantle Arts Centre Press, 1995); Nevile Green, "Review of Christine Halse, 'A Terribly Wild Man: A Biography of the Rev Ernest Gribble'." Aboriginal History 26 (2002): 270-272; Christine Halse, A terribly wild man. (Crows Nest: N.S.W., Allen \& Unwin, 2002); Rod Moran, Massacre myth : an investigation into allegations concerning the mass murder of Aborigines at Forrest River, 1926 (Bassendean, W.A., Access Press, 1999). 
Finnane and Paisley: Police violence on a colonial frontier

${ }^{43}$ Markus, Governing savages; Fiona Paisley, Loving protection? : Australian feminism and aboriginal women's rights 1919-1939 (Carlton South, Vic.: Melbourne University Press, 2000).

${ }^{44}$ Melbourne Herald, 22 July 1933, clipping in NAA A1 (A1/15), 33/5423.

${ }^{45}$ Chave Collisson to Stanley Bruce, no date, c. June 1933, and J. McLaren, Secretary, Australia House, to the Secretary, Prime Minister’s Department, Canberra, 15 May, 1933, NAA A1 (A1/15) 1933/5423.

${ }^{46}$ As stated by Morley, for the APNR, to JA Perkins, the Minister for the Interior, 'as a member of the League of Nations we are morally bound to frame and work some policy designed to raise our Aboriginal race, and to solve by a well-considered policy the problem of cultural and racial clash...', Morley to Perkins, 2 February 1934, NAA A1 (A1/15) $1933 / 5423$.

${ }^{47}$ Knowles to Interior, 3 Apr 1933; Administrator (Darwin) to Interior, 15 Mar 1933 ,NAA A1; JA Perkins (Minister for Interior) to Morley, 2 Jun 1933, NAA A1 (A1/15) 1933/5423. ${ }^{48}$ Telegram from Administrator, Darwin, 15 March 1933 - Weddell hoped that such a court might determine matters such as the appeal over the convictions at Borroloola where 'it is possible they were afraid of police constable', NAA A1 (A1/15) 1933/5423.

49 John Harris, Honorary Secretary of the Anti-Slavery Society, to the International Law Association, 5 June, 1934, Mss Brit Emp s22, G376 Australian Aborigines (Bodleian Library). Concerning the context of the 'Black Peril' under which cases appeared in Southern Rhodesian courts. see Jock McCulloch, Black Peril, White Virtue: Sexual Crime in Southern

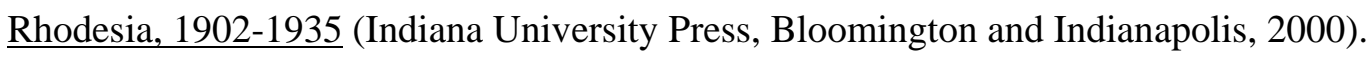

${ }^{50}$ Australian Committee, ASAPS, to J.A. Lyons, PM, 21 June 1935 and 6 March, 1936. Mss Brit Emp s22, G377 Australian Aborigines, 1934-36 re Native Courts. 
Finnane and Paisley: Police violence on a colonial frontier

${ }^{51}$ M.M. Bennett to Sir John Harris, ASAPS, October 20 1935. Mss Brit Emp s22, G377

Australian Aborigines 1934-36 re Native Courts.

52 Melbourne Herald, 13 Nov 1933, NAA A1 (A1/15), 1933/5423.

53 ‘Alleged Assault of Aboriginal: Conduct of Inquiry: Judge’s Criticism’, unsourced newspaper clipping, NAA A1 (A1/15), 1933/5423.

54 'Supreme Court’, Northern Standard, 24 April, 1934, NAA A1 (A1/15), 1933/5423.

${ }^{55}$ John Harris to Edith Jones, 31 August 1934, G376 Australian Aborigines, ASAPS papers MSS Brit Emp s22.

${ }^{56}$ Canberra Times, 25 Apr 1934, NAA A1 (A1/15), 1933/5423.

${ }^{57}$ Ted Egan, Justice all their own: The Caledon Bay and Woodah Island Killings 1932-1933

(Melbourne, Melbourne University Press, 1996); Peter Read, "Murder, revenge and reconciliation on the North Eastern frontier: [Paper delivered as the Keynote Address at the Annual Meeting of the Australian Historical Association, July 2005.]." History Australia 4(1) (2007): 09.1-09.15; Tuckiar v R (High Court of Australia), 52 CLR 335 (1934).

${ }^{58}$ Peter Elder, “Wells, Thomas Alexander (1888 - 1954)” Australian Dictionary of Biography. (Melbourne, Melbourne University Press, 2002, 16: 521) http://www.adb.online.anu.edu.au/biogs/A130002b.htm?hilite=abbott\%3Bcharles (8 Jan 2009); Markus, Governing savages; Egan, Justice all their own; Army service record at NAA B2455/1 'WELLS THOMAS ALEXANDER'

http://naa12.naa.gov.au/scripts/imagine.asp?B=8380708\&I=1\&SE=1 (8 Jan 2009).

${ }^{59}$ Northern Territory, Ordinance no 21933 (24 May 1933).

${ }^{60}$ Wells to Interior, 25 Nov 1933 and 27 Nov 1933, NAA A1(A1/15), 1933/5423.

${ }^{61}$ Cahill to Morley, nd, copy provided by Morley to Perkins, Minister for Interior, 5 Feb 1934, NAA A1 (A1/15) 1933-5423 (fol 215-217).

${ }^{62}$ Cook to Weddell, 14 Nov 1933, NAA A1 (A1/15) 1933/5423 
Finnane and Paisley: Police violence on a colonial frontier

${ }^{63}$ The sentence was subsequently commuted to life imprisonment: NAA A1 (A1/15) 1933/8560.

${ }^{64}$ Egan, Justice all their own.

65 Telegram received Department of Interior, 24 April 1934, NAA A1 (A1/15) 1933/5423 (fols 253-257).

${ }^{66}$ Carrodus to Interior, 28 Apr 1934, NAA A1 (A1/15) 1933/5423.

${ }^{67}$ See especially Markus, Governing savages; Fiona Paisley, “Race Hysteria: Darwin 1938”, Bodies in Contact: Rethinking Colonial Encounters in World History, eds T. Ballantyne and A. Burton. (Durham, NC, Duke University Press 2005): 234-252.. In 1939 Wells was personally rebuked by then Attorney-General (and soon-to-be Prime Minister) Robert Menzies for comments on public policy, administration and the law made during the course of a sentencing determination: see the file 'Flogging of natives', NAA A432 1938/578. ${ }^{68}$ See especially Attwood, Rights for aborigines; Heather Goodall, Invasion to embassy : land in Aboriginal politics in New South Wales, 1770-1972 (St. Leonards, NSW: Allen \& Unwin, 1996); Haebich, Broken circles; Rosalind Kidd, The way we civilise : Aboriginal affairs - the untold story (St Lucia, Qld: University of Queensland Press, 1997).

${ }^{69}$ See Kate Auty, Black glass : Western Australian courts of native affairs 1936-54

(Fremantle, WA: Fremantle Arts Centre Press, 2005); Elizabeth M. Eggleston, Fear, favour or affection : Aborigines and the criminal law in Victoria, South Australia and Western Australia (Canberra, Australian National University Press, 1976).

${ }^{70}$ Mark Finnane, When police unionise: the politics of law and order in Australia (Sydney: Sydney Institute of Criminology, 2002).

${ }^{71}$ J. Warden, "T. G. H. Strehlow and the 1935 Board of Inquiry into the Alleged IllTreatment of Aborigines”, in Traditions in the midst of change : communities, cultures and the Strehlow legacy in Central Australia : proceedings of the Strehlow Conference, Alice 
Finnane and Paisley: Police violence on a colonial frontier

Springs 18-20 September 2002 ed. M. Cawthorn (Alice Springs, NT: Strehlow Research Centre, 2004: 89-100).

72 Jeremy P M Long, The go-betweens : patrol officers in Aboriginal affairs administration in the Northern Territory 1936-74 (Casuarina, NT: North Australia Research Unit Australian National University, 1992); Markus Governing savages; Rowse, White Flour, White Power.

${ }^{73}$ Morley (or possibly Elkin) to Rev. J. Jones, 14 December 1937, APNR Papers. S.55, Series 1, University of Sydney Archives. 